\title{
Influence of antacid and formulation on effectiveness of pancreatic enzyme supplementation in cystic fibrosis
}

\author{
C BRAGGION, G BORGO, P FAGGIONATO, AND G MASTELLA \\ Veneto Regional Research Centre for Cystic Fibrosis, Verona, Italy
}

SUMMARY A series of treatment trials, involving food balances based on determination of fat coefficient absorption, nitrogen faecal loss, and daily faecal weight, was performed in 82 patients with cystic fibrosis.

Results showed that a conventional powdered pancreatic extract (Pancrex V) required a high dosage to achieve reasonable improvement in fat and nitrogen absorption $(200 \mathrm{mg} / \mathrm{kg}$ body weight/day on average) and rarely restored digestion to normal. Bicarbonate $\left(5 \cdot 2 \mathrm{~g} / \mathrm{m}^{2}\right.$ body surface/day) slightly enhanced the enzymatic activity of the powdered extract, this being more apparent in those with more severe steatorrhoea. There was no advantage in providing the extract in microgranules protected by cellulose acetatephthalate. A product based on fungal lipase and protease (Krebsilasi) proved to be ineffective in correcting fat and protein absorption. The two recent products prepared in $\mathrm{pH}$ sensitive microspheres (Pancrex $\mathrm{V}$ microspheres and Pancrease-Prolipase) had similar advantages in digestive activity. Compared with the traditional preparations, they offered a number of practical advantages, including a smaller number of capsules (particularly Pancrex V microspheres) and improved palatability.

Cystic fibrosis is by far the most common cause of pancreatic insufficiency in children.

The use of concentrated pancreatic extracts, obtained mainly from hog pancreas, has played a considerable part for many years in improving the nutritional state of fibrocystic patients. ${ }^{1-5}$ But the limitations of conventional pancreatic extracts have become very apparent, especially in the management of steatorrhoea. ${ }^{3-5}$ Inactivation by the peptic and acid secretion of the stomach plays a fundamental part in this. In the adult it has been shown that only $8 \%$ of lipolytic activity and $22 \%$ of proteolytic activity administered by mouth can be recovered from the loop of Treitz. ${ }^{6}$ Digestion and absorption of lipids are then further impaired in this disease by deficient secretion of bicarbonate, preventing optimisation of intestinal $\mathrm{pH}$ for lipase activity and by deficient lipid micellation due to the reduced pool of bile acids, which are then reabsorbed poorly at the level of the ileum. ${ }^{37}$

Repeated attempts to overcome the gastric effects by formulating the extract in gastroresistant tablets or in granules coated with cellulose acetatephthalate have met with little success.
Few trials have been performed with enzymes of vegetable or bacterial origin, which would have the advantage of not being inactivated in an acid $\mathrm{pH}^{8}{ }^{9}$ Lingual lipase, whose excellent activity in an acid medium is well known, has not yet been made available for therapeutic use. ${ }^{10}$ Use of massive doses of extract has been the main means of overcoming gastric inactivation. ${ }^{4}$ The combined administration of antacids (sodium bicarbonate, aluminium hydroxide, etc) or $\mathrm{H}_{2}$ receptor antagonists, to reduce gastric acid secretion, has given conflicting results. ${ }^{11-13}$

A more favourable reception has recently been given to extracts made up in $\mathrm{pH}$ sensitive, gastroprotected, and enterosoluble microspheres. These microspheres are stable at $\mathrm{pHs}$ below 5.5 and hence the extract is not inactivated in the stomach, while the enzymatic activity is released in 15-30 minutes in an alkaline medium and hence is activated in the small intestine. ${ }^{14}$ The small size of the microspheres (diameter less than $3 \mathrm{~mm}$ ) also allows homogeneous distribution of the extract in the food. Several controlled clinical studies in patients with cystic fibrosis have shown the effectiveness of these 
extracts, even if the results are not in complete agreement. Some studies have shown that fat and protein absorption improves compared with conventional extract. ${ }^{15-17}$ Others have produced results similar to those obtained with conventional extracts but with a definitely lower daily number of capsules and without the unpleasant taste of the powdered pancreatic extract, thus leading to better therapeutic compliance. $^{2} 131418$

Interpretation of these clinical trials is generally difficult because of the small number of patients studied, especially as it is a therapeutic field in which individual variability plays an important part in influencing the results. This study describes research into the possible beneficial effect of antacids, looks at any advantages of pancreatic extracts in $\mathrm{pH}$ sensitive microspheres, and compares the old and new extracts available on the market today, using a larger number of patients with cystic fibrosis.

\section{Patients and methods}

In all patients included in this study the diagnosis of cystic fibrosis was made on the basis of at least two sweat tests, using the Gibson and Cooke procedure.

In most of the patients a study was then made of pancreatic function by duodenal intubation, stimulation with a secretin-pancreozymin bolus $(2 \mathrm{U} / \mathrm{kg}$ body weight), and determination of the enzyme and bicarbonate output for 30 minutes. ${ }^{19}$ In addition, a food balance was carried out for three to four days, with determination of the coefficient of fat absorption (ACfat), faecal nitrogen loss, and daily faecal weight. The food balance during treatment with pancreatic extracts or antacids was made under hospital conditions: the start and end of each balance was marked by oral administration of carmine. During each balance a diet was given with strictly controlled fat content (from 2 to $4 \mathrm{~g} / \mathrm{kg}$ /day according to age; average $3 \mathrm{~g} / \mathrm{kg} /$ day), while the protein and carbohydrate content were balanced but uncontrolled. When pancreatic extracts were administered the number of capsules given each day was calculated and rounded individually around the chosen dosage, distributed over the four daily meals and divided during the meal into start, middle, and end. When two extracts were compared in the same subjects priority was randomly assigned.

The following variables were recorded for the faeces in each period: faecal fats by Van de Kamer's method, as modified by Jeejeebhoy for medium chain triglyceride fats, ${ }^{20}$ with calculation of the coefficient of absorption, and daily faecal nitrogen determined on a Carlo Erba ANA automatic analyser. ${ }^{21}$ The means of the results obtained for paired groups were compared by Student's $t$ test.

Consent was obtained from the parents or patients, or both, after adequate explanation.

The declared characteristics and composition of the different pancreatic extracts used are set out in Table 1.

The gastroprotective coating of the two $\mathrm{pH}$ sensitive compounds is made from cellulose acetatephthalate, plasticised with diethylphthalate. Of the other excipients, which are the main constituents of microsphere cores, the composition was available

Table 1 Declared characteristics and composition of the different pancreatic extracts used

\begin{tabular}{|c|c|c|c|c|c|c|}
\hline \multirow{2}{*}{$\begin{array}{l}\text { Pancreatic } \\
\text { extract } \\
\text { (Manufacturers) }\end{array}$} & \multirow{2}{*}{$\begin{array}{l}\text { Form of } \\
\text { preparation* }\end{array}$} & \multirow{2}{*}{$\begin{array}{l}\text { Weight of } \\
\text { contents of one } \\
\text { capsule ( } \mathrm{mg})\end{array}$} & \multirow{2}{*}{$\begin{array}{l}\text { Declared active } \\
\text { substance }\end{array}$} & \multicolumn{3}{|c|}{ Declared content of FIP $P^{\dagger}$ units in one capsule } \\
\hline & & & & Lipase & Amylase & Protease \\
\hline $\begin{array}{l}\text { Pancrex V powder } \\
\text { (Samil-Pabyrn) }\end{array}$ & $\begin{array}{l}\text { Powder } \\
\quad \text { (in capsules) }\end{array}$ & 340 & $\begin{array}{l}\text { Pig pancreatin } \\
\text { BP } 340 \mathrm{mg}\end{array}$ & 13000 & 10500 & 550 \\
\hline $\begin{array}{l}\text { Pancrex V granular } \\
\text { (Samil-Pabyrn) } \dagger\end{array}$ & $\begin{array}{l}\text { Gastroresistant } \\
\text { microgranules } \\
\text { (cellulose acetate- } \\
\text { phthalate) in capsules }\end{array}$ & 500 & $\begin{array}{l}\text { Pig pancreatin } \\
\text { BP } 420 \mathrm{mg}\end{array}$ & 15000 & 13000 & 680 \\
\hline $\begin{array}{l}\text { Pancrex V microsphere } \\
\text { (Samil-Pabyrn) }\end{array}$ & $\begin{array}{l}\text { Gastroresistant. } \\
\text { enterosoluble. } \\
\text { pH sensitive } \\
\text { microspheres } \\
\text { in capsules }\end{array}$ & $5(x)$ & $\begin{array}{l}\text { Pig pancreatin } \\
\text { BP } 340 \mathrm{mg}\end{array}$ & 13000 & 10500 & 550 \\
\hline $\begin{array}{l}\text { Pancrease-Prolipase } \\
\text { (Cilag) }\end{array}$ & $\begin{array}{l}\text { Acid resistant, } \\
\text { enterosoluble, } \\
\text { pH sensitive } \\
\text { microspheres } \\
\text { (in capsules) }\end{array}$ & 420 & Pig pancrelipase & 5000 & 2900 & 330 \\
\hline
\end{tabular}

${ }^{*}$ All the enzymatic preparations are contained in hard gelatin capsules.

The granular preparation in the Italian market has different characteristics from a similar preparation in Britain.

†FIP=Federation Internationale Pharmaceutique. 
for the Pancrex $\mathrm{V}$ microspheres* only-namely, amidocarboxyethylate, polyvinyl pyrrolidone, saccharose, starch, talc, and E171.

The dosage of pancreatic extracts was standardised on the basis of our previous study, ${ }^{4}$ in which a relation between dose and effect was found for Pancrex V powder: $200 \mathrm{mg} / \mathrm{kg} / \mathrm{day}$, corresponding to about $75 \mathrm{mg}$ of extract per gram of fat administered, resulted in the most acceptable and reasonable dose. Adequate adjustments were made for the new preparations Pancrease-Prolipase and Pancrex V microspheres.

The overall study was made in successive stages as briefly described below.

Phase I: effect of sodium bicarbonate. The effect of sodium bicarbonate in combination with Pancrex V powder was tested in 40 patients with cystic fibrosis. Of these, 26 (mean (SD) age 5.09 (4.12) years) were treated with this conventional extract and then with the same extract plus sodium bicarbonate $\left(5 \cdot 2 \mathrm{~g} / \mathrm{m}^{2}\right.$ body surface/day). The other 14 (mean (SD) age $5.56(4.05)$ years) constituted the control group, in whom the only treatment, alternating with two basal balance phases, was sodium bicarbonate.

Phase II: comparison between conventional powdered pancreatic extracts and gastroresistant granules. Pancrex V powder and Pancrex V microgranules $\dagger$ were compared in six patients with cystic fibrosis (mean (SD) age $10 \cdot 2(5 \cdot 3)$ years) according to the same dosage as in phase $I$.

Phase III: comparison between conventional powdered pancreatic extracts and extracts in pH sensitive, gastroprotected, and enterosoluble microspheres. Three comparative trials were made in succession (Table 2).

(A) Pancrex $\mathrm{V}$ powder versus a $\mathrm{pH}$ sensitive extract (Pancrease-Prolipase) in 11 patients with

*Pancrex $\mathrm{V}$ microspheres are not commercially available at the time of writing.

†Pancrex $\mathrm{V}$ microgranules in capsules are an experimental formulation not commercially available. cystic fibrosis (mean (SD) age $9 \cdot 5(4 \cdot 2)$ years) with the same quantity of extract by weight.

(B) Pancrex $\mathrm{V}$ powder versus a second $\mathrm{pH}$ sensitive extract (Pancrex $\mathrm{V}$ microspheres) in 10 patients with cystic fibrosis (mean (SD) age 8.3 (4.7) years). For Pancrex $\mathrm{V}$ microspheres it was decided to administer a dose that would provide lipase activity equal to that of the administration of Pancrease-Prolipase in the preceding group.

(C) The first (Pancrease-Prolipase) versus the second (Pancrex $\mathrm{V}$ microspheres) $\mathrm{pH}$ sensitive extract in 10 patients with cystic fibrosis (mean (SD) age 10.6 (6.1) years). The dosage used for ProlipasePancrease was $70-100 \mathrm{mg} / \mathrm{g}$ fat and for Pancrex V microspheres was a quantity by weight that would supply the same activity as the preceding extract $(35-50 \mathrm{mg} / \mathrm{g}$ fat $)$.

It should be pointed out that, in view of the presumed advantages of the $\mathrm{pH}$ sensitive compounds, the quantity of lipase activity administered with these corresponded to about a third of the lipase activity of Pancrex V powder.

For the preparations administered to infants unable to swallow capsules, the microspheres were mixed with grated apple, which has an acid $\mathrm{pH}$ : this procedure did not create any problems.

Phase IV: pancreatin with enzymes of fungal origin. The digestive effect of the product Krebsilasi (pancreatin with enzymes of fungal origin) was studied, with the criteria previously described, in five patients with cystic fibrosis (mean (SD) age $8.1(1.8)$ years) in comparison with their baseline digestive situation. With regard to dosage, the mean (SD) quantity of capsules (12 (1.7) per day) administered each day was such as to supply a lipase activity roughly equal to that of the $\mathrm{pH}$ sensitive formulations (1496.4 (277.8) FIP (Federation Internationale Pharmaceutique) lipase units per gram of fats administered).

\section{Results}

Effect of bicarbonate. Figure 1 shows individual and

Table 2 Treatment schedule with different pancreatic extracts in five groups of patients. Values are mean (SD) [range] except where stated

\begin{tabular}{|c|c|c|c|c|c|c|c|c|c|c|c|c|}
\hline Group & $\begin{array}{l}\text { No of } \\
\text { patients }\end{array}$ & $\begin{array}{l}\text { Baseline } \\
\text { ACfat (\%) }\end{array}$ & $\begin{array}{l}\text { First } \\
\text { pancreatic } \\
\text { extract }\end{array}$ & $\begin{array}{l}\text { Mean }(S D) \\
\text { No of } \\
\text { capsules/day }\end{array}$ & ACfat $(\%)$ & $\begin{array}{l}\text { Faecal } \\
\text { nitrogen } \\
\text { (g/day) }\end{array}$ & $\begin{array}{l}\text { Faecal } \\
\text { weight } \\
\text { (g/day) }\end{array}$ & $\begin{array}{l}\text { Second } \\
\text { pancreatic } \\
\text { extract }\end{array}$ & $\begin{array}{l}\text { Mean }(S D) \\
\text { No of } \\
\text { capsules/day }\end{array}$ & ACfat (\%) & $\begin{array}{l}\text { Faecal } \\
\text { nitrogen } \\
\text { (g/day) }\end{array}$ & $\begin{array}{l}\text { Faecal } \\
\text { weight } \\
\text { (g/day) }\end{array}$ \\
\hline 1 & 6 & $\begin{array}{r}36 \cdot 2(16 \cdot 6) \\
{[21 \cdot 6-65 \cdot 8]}\end{array}$ & $\begin{array}{c}\text { Pancrex V } \\
\text { powder }\end{array}$ & $16 \cdot 3(3 \cdot 3)$ & $\begin{array}{l}65 \cdot 7(16 \cdot 8) \\
{[35 \cdot 7-82 \cdot 8]}\end{array}$ & $\begin{array}{c}2.73(1.17) \\
{[1.41-4.74]}\end{array}$ & $\begin{array}{c}265(159) \\
{[137-601]}\end{array}$ & $\begin{array}{l}\text { Pancrex V } \\
\text { microgranules }\end{array}$ & $16 \cdot 3(3.3)$ & $\begin{array}{c}68 \cdot 1(22 \cdot 1) \\
{[30 \cdot 7-87 \cdot 2]}\end{array}$ & $\begin{array}{c}2.23(1.30) \\
{[1.21-5.09]}\end{array}$ & $\begin{array}{r}216(131) \\
{[124-507]}\end{array}$ \\
\hline 2 & 11 & $\begin{array}{c}41 \cdot 1(14 \cdot 7) \\
{[19 \cdot 0-73 \cdot 0]}\end{array}$ & $\begin{array}{c}\text { Pancrex V } \\
\text { powder }\end{array}$ & $16.3(2.0)$ & $\begin{array}{l}70 \cdot 7(21 \cdot 6) \\
{[22 \cdot 3-93 \cdot 7]}\end{array}$ & $\begin{array}{c}2.03(1.14) \\
{[0 \cdot 85-4 \cdot 50]}\end{array}$ & $\begin{array}{l}207(90) \\
{[79-442]}\end{array}$ & $\begin{array}{l}\text { Pancrease- } \\
\text { Prolipase }\end{array}$ & $14.0(1.7)$ & $\begin{array}{c}86 \cdot 2(13 \cdot 5) \\
{[47 \cdot 3-97 \cdot 2]}\end{array}$ & $\begin{array}{l}1.40(0.26) \\
{[1 \cdot 10-2 \cdot 09]}\end{array}$ & $\begin{array}{r}168(37) \\
{[107-259]}\end{array}$ \\
\hline 3 & 10 & $\begin{array}{l}48.8(15.8) \\
{[25.0-65.6]}\end{array}$ & $\begin{array}{c}\text { Pancrex V } \\
\text { powder }\end{array}$ & $16.8(3.8)$ & $\begin{array}{l}78 \cdot 2(16 \cdot 2) \\
{[52 \cdot 1-96 \cdot 7]}\end{array}$ & $\begin{array}{l}1.46(0.37) \\
{[0.87-2 \cdot 20]}\end{array}$ & $\begin{array}{l}137(57) \\
{[77-228]}\end{array}$ & $\begin{array}{l}\text { Pancrex y } \\
\text { microspheres }\end{array}$ & $7.0(1.0)$ & $\begin{array}{c}83.9(11.8) \\
{[55.2-96.0]}\end{array}$ & $\begin{array}{l}1.59(0.44) \\
{[1.01-2.37]}\end{array}$ & $\begin{array}{r}177(52) \\
{[115-292]}\end{array}$ \\
\hline 4 & 10 & $\begin{array}{c}44.3(18.9) \\
{[27.0-66.2]}\end{array}$ & $\begin{array}{c}\text { Pancrease- } \\
\text { Prolipase }\end{array}$ & $14.6(3.4)$ & $\begin{array}{r}87 \cdot 3(6 \cdot 3) \\
{[73 \cdot 3-93 \cdot 9]}\end{array}$ & $\begin{array}{c}1.98(0.98) \\
{[0.78-3.81]}\end{array}$ & $\begin{array}{l}181(97) \\
{[72-420]}\end{array}$ & $\begin{array}{l}\text { Pancrex V } \\
\text { microspheres }\end{array}$ & $6.6(1.2)$ & $\begin{array}{r}86.5(7.6) \\
{[66.9-95.4]}\end{array}$ & $\begin{array}{c}2.09(1.46) \\
{[0.90-5.85]}\end{array}$ & $\begin{array}{l}162 \text { (96) } \\
{[73-384]}\end{array}$ \\
\hline
\end{tabular}



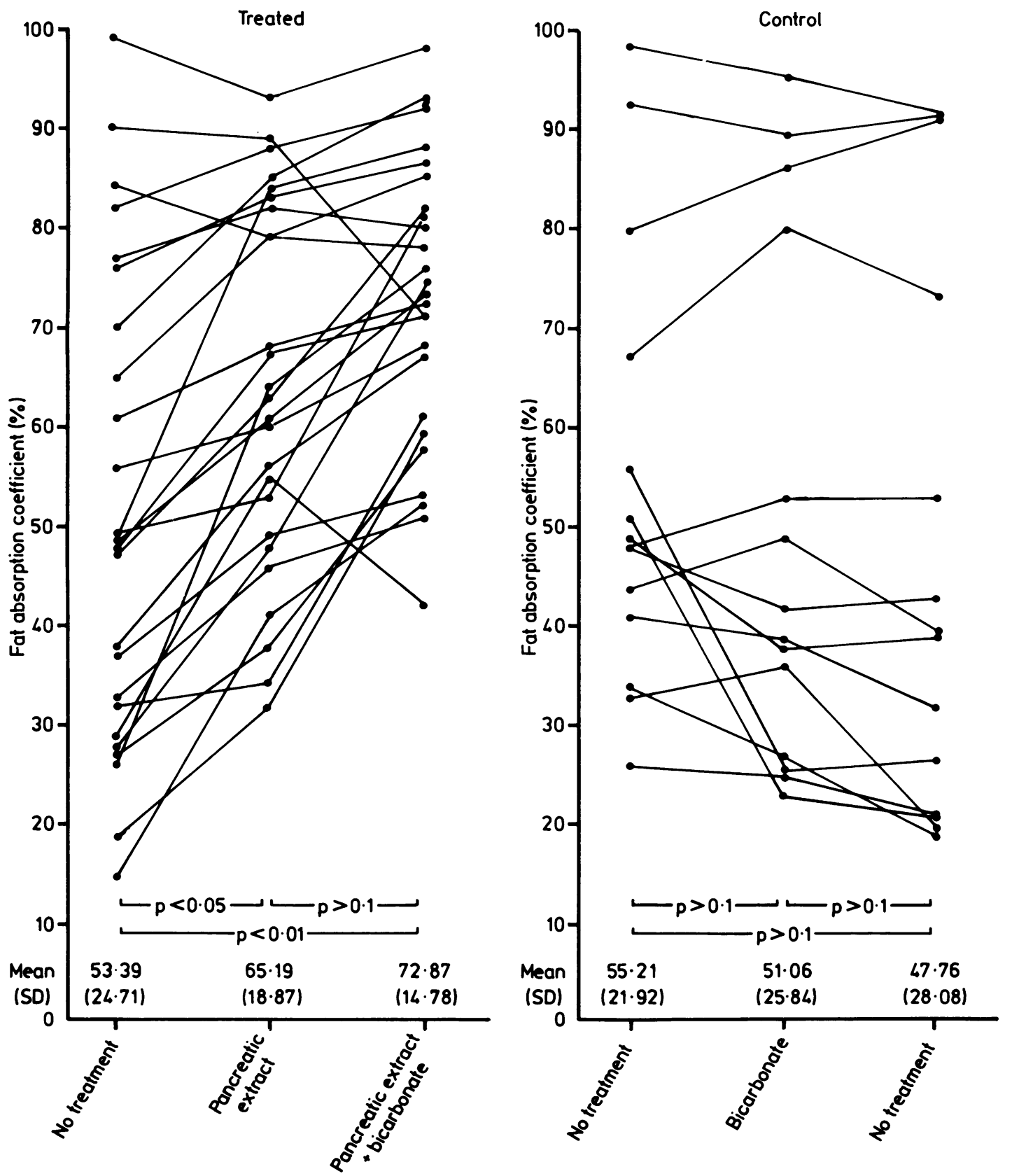

Fig. 1 Fat absorption coefficient, obtained by three subsequent food balances in different treatment conditions in two groups of patients with cystic fibrosis. The 'treated' group received pancreatic extract (Pancrex V powder, about $200 \mathrm{mg} / \mathrm{kg}$ body weight/day) or pancreatic extract (Pancrex $V$, same dose) plus sodium bicarbonate (about $5 \cdot 2 \mathrm{~g} / \mathrm{m}^{2}$ body surface/day); the 'control' group was treated with sodium bicarbonate alone $\left(5 \cdot 2 \mathrm{~g} / \mathrm{m}^{2}\right.$ body surfacelday). 
mean changes obtained in ACfat in patients with cystic fibrosis through the effect of pancreatic extract (Pancrex V powder) and through the effect of combining sodium bicarbonate with the extract, in comparison with a group of patients with cystic fibrosis treated with sodium bicarbonate alone. It is clear that by itself bicarbonate did not produce any effect, while its effect in combination with the extract was measurable but of little importance. There was a wide variation in response, presumably linked to the baseline absorption condition. Bicarbonate seemed in fact to have an enhancing effect on lipase activity, which was higher for patients with lower baseline ACfat; in patients with a baseline ACfat over $75 \%$ bicarbonate proved to be completely ineffective. Figure 2 shows individual and mean changes obtained for daily nitrogen loss in the same groups of subjects under the same treatment conditions. There was the usual wide variability of results, evident even in the control group.

Combining bicarbonate with the extract did not seem to affect the degree of azotorrhoea found with the extract alone. No change was observed in acid base equilibrium of the blood with the bicarbonate dosage used.

Comparison between two commercial forms of concentrated pancreatic extract (powder and microgranules). The results showed no differences between the mean values of ACfat, azotorrhoea, and daily faecal weight (Table 2). In view of these results, a fuller comparison was not made.

Evaluation of pancreatic extracts in gastroresistant and enterosoluble microspheres. (Fig. 3) The mean value of ACfat was about $86 \%$ with PancreaseProlipase compared with $71 \%$ with the conventional Pancrex V powder $(p<0 \cdot 05)$; there was no significant difference, on the other hand, as regards faecal nitrogen and daily faecal weight (Table 2). The ACfat obtained with Pancrex V microspheres was on average higher than that obtained with Pancrex $\mathrm{V}$ powder, even though the difference was not significant. There were no significant differences as regards azotorrhoea and daily faecal weight (Table 2).

In 10 patients the direct comparison between Pancrease-Prolipase and Pancrex V microspheres showed similar results for ACfat (average $87 \%$ and $86 \%$, respectively), faecal nitrogen (mean 1.98 $\mathrm{g} /$ day and $2.09 \mathrm{~g} /$ day, respectively), and daily faecal weight $(180 \mathrm{~g} / \mathrm{day}$ and $160 \mathrm{~g} /$ day, respectively).

When the individual cases were examined the results were still similar.

Cumulative results. The overall data of the comparative clinical trials covered by the last two subheadings are summarised in Table 3, combining the cases from all treatment groups.

It can be seen that the $\mathrm{pH}$ sensitive formulations were more effective than the conventional ones as regards fat absorption, while there was no significant difference for loss of faecal nitrogen or daily faecal weight. Likewise, the comparison between the conventional powdered extract and its form in gastroprotected microspheres (Pancrex V), which showed no significant differences in the small trial, showed definite advantages for the microsphere form when all patients were considered together.

This effect was obtained with a lower activity of lipase per gram of fat and a decidedly smaller number of capsules each day. With the new gastroprotected and enterosoluble compounds mean ACfat values of about $85 \%$ were obtained: out of a total of 31 patients and a total number of 41 food balances, during which one or other of these extracts was administered, the improvement in digestion was excellent (ACfat over $90 \%$ ) in 18, good (ACfat

Table 3 Cumulative comparison between four types of pancreatic extract, with determination of fat absorption coefficient (ACfat), daily faecal nitrogen, and daily faecal weight ( 74 food balance tests in 37 patients with cystic fibrosis)

\begin{tabular}{|c|c|c|c|c|c|c|c|c|c|}
\hline \multirow[t]{2}{*}{ Pancreatic extract } & \multirow{2}{*}{$\begin{array}{l}\text { No of } \\
\text { food } \\
\text { balance } \\
\text { tests }\end{array}$} & \multirow{2}{*}{$\begin{array}{l}\text { Mean }(S D) \\
\text { age } \\
\text { (years) }\end{array}$} & \multirow{2}{*}{$\begin{array}{l}\text { Mean }(S D) \\
\text { No of } \\
\text { capsules/kg/ } \\
\text { day }\end{array}$} & \multirow{2}{*}{$\begin{array}{l}\text { Mean (SD) } \\
\text { FIP lipase } \\
\text { units per } \\
\text { gram of fat } \\
\text { administered }\end{array}$} & \multirow{2}{*}{$\begin{array}{l}\text { Mean (SD) } \\
\text { FIP Protease } \\
\text { units per } \\
\text { gram of fat } \\
\text { administered }\end{array}$} & \multirow{2}{*}{$\begin{array}{l}\text { Mean (SD) } \\
\text { [range] } \\
\text { baseline } \\
\text { ACfat }(\%)\end{array}$} & \multicolumn{3}{|c|}{ On treatment (mean $(S D)$ [range/) } \\
\hline & & & & & & & ACfat $(\%)$ & $\begin{array}{l}\text { Faecal } \\
\text { nitrogen } \\
\text { (g/day) }\end{array}$ & $\begin{array}{l}\text { Faecal } \\
\text { weight } \\
\text { (g/day) }\end{array}$ \\
\hline Pancrex V powder & 27 & $9 \cdot 2(4 \cdot 7)$ & $0.74(0.20)$ & $3313 \cdot 1(506 \cdot 9)$ & $140 \cdot 1(21 \cdot 4)$ & $\begin{array}{c}47 \cdot 8(16 \cdot 5) \\
{[18 \cdot 3-79 \cdot 1]}\end{array}$ & $\begin{array}{c}72 \cdot 3(19 \cdot 3) \\
{[22 \cdot 3-97 \cdot 1]}\end{array}$ & $\begin{array}{c}1.97(1.05) \\
{[9.85-4.74]}\end{array}$ & $\begin{array}{l}194 \cdot 1(111 \cdot 9) \\
{[77-601]}\end{array}$ \\
\hline Pancrex V microgranules & 6 & $10 \cdot 2(5 \cdot 3)$ & $0.70(0 \cdot 15)$ & $3182 \cdot 0(477 \cdot 8)$ & $166.4(24.9)$ & $\begin{array}{c}36 \cdot 2(16 \cdot 6) \\
{[18 \cdot 3-65 \cdot 8]}\end{array}$ & $\begin{array}{c}68 \cdot 1(22 \cdot 1) \\
{[30 \cdot 7-94 \cdot 4]}\end{array}$ & $\begin{array}{c}2.23(1.30) \\
{[1.21-5.09]}\end{array}$ & $\begin{array}{l}216 \cdot 4(131 \cdot 0) \\
{[124-507]}\end{array}$ \\
\hline Pancrease-Prolipase & 21 & $10 \cdot 0(5 \cdot 2)$ & $0.54(0 \cdot 18)$ & $1034 \cdot 8(180 \cdot 2)$ & $68.2(11 \cdot 8)$ & $\begin{array}{l}42 \cdot 8(17 \cdot 2) \\
{[4 \cdot 0-73 \cdot 0]}\end{array}$ & $\begin{array}{c}86 \cdot 7(10 \cdot 7) \\
{[47.3-97 \cdot 2]}\end{array}$ & $\begin{array}{c}1.68(0.76) \\
{[0.78-3.81]}\end{array}$ & $\begin{array}{l}174 \cdot 1(72 \cdot 4) \\
|72-420|\end{array}$ \\
\hline Pancrex $\mathrm{V}$ microspheres & 20 & $9 \cdot 4(5 \cdot 5)$ & $0 \cdot 25(0 \cdot 14)$ & $1327 \cdot 7(457 \cdot 6)$ & $56 \cdot 1(19 \cdot 3)$ & $\begin{array}{l}46 \cdot 4(17 \cdot 7) \\
{[4 \cdot 0-79 \cdot 1]}\end{array}$ & $\begin{array}{c}85 \cdot 2(10.0) \\
{[55 \cdot 2-96 \cdot 0]}\end{array}$ & $\begin{array}{c}1.84(1.10) \\
{[0.90-5.85]}\end{array}$ & $\begin{array}{l}169 \cdot 5(77 \cdot 7) \\
{[73-384]}\end{array}$ \\
\hline
\end{tabular}

Comparison of means between treatments $(S=$ significant $(p<0.05)$; SS = highly significant $(p<0.01)$; NS $=$ not significant $(p>0.05))$ :

\begin{tabular}{|c|c|c|c|c|c|c|c|}
\hline & $\begin{array}{l}\text { ACfat: } \\
p>0.6 \text { (NS) }\end{array}$ & $\begin{array}{l}\text { Faecal nitrogen: } \\
p>0.6 \text { (NS) }\end{array}$ & $\begin{array}{l}\text { Faecal weight: } \\
p>0 \cdot 8 \text { (NS) }\end{array}$ & & $\begin{array}{l}\text { ACfat: } \\
\text { p<0.05 (S) }\end{array}$ & $\begin{array}{l}\text { Faecal nitrogen: } \\
p>0.3 \text { (NS) }\end{array}$ & $\begin{array}{l}\text { Faecal weight: } \\
p>0.4 \text { (NS) }\end{array}$ \\
\hline & $\mathrm{p}<0.01$ (SS) & $p>0.2$ (NS) & $\mathrm{p}>0.4$ (NS) & & $p<0.05$ (S) & $p>0.5$ (NS) & $p>0.4$ (NS) \\
\hline & $\mathrm{p}<0.01$ (SS) & $p>0.6$ (NS) & $p>0.3$ (NS) & $3 \times 4$ & $p>0.6$ (NS) & $p>0.5$ (NS) & $p>0.8$ (NS) \\
\hline
\end{tabular}




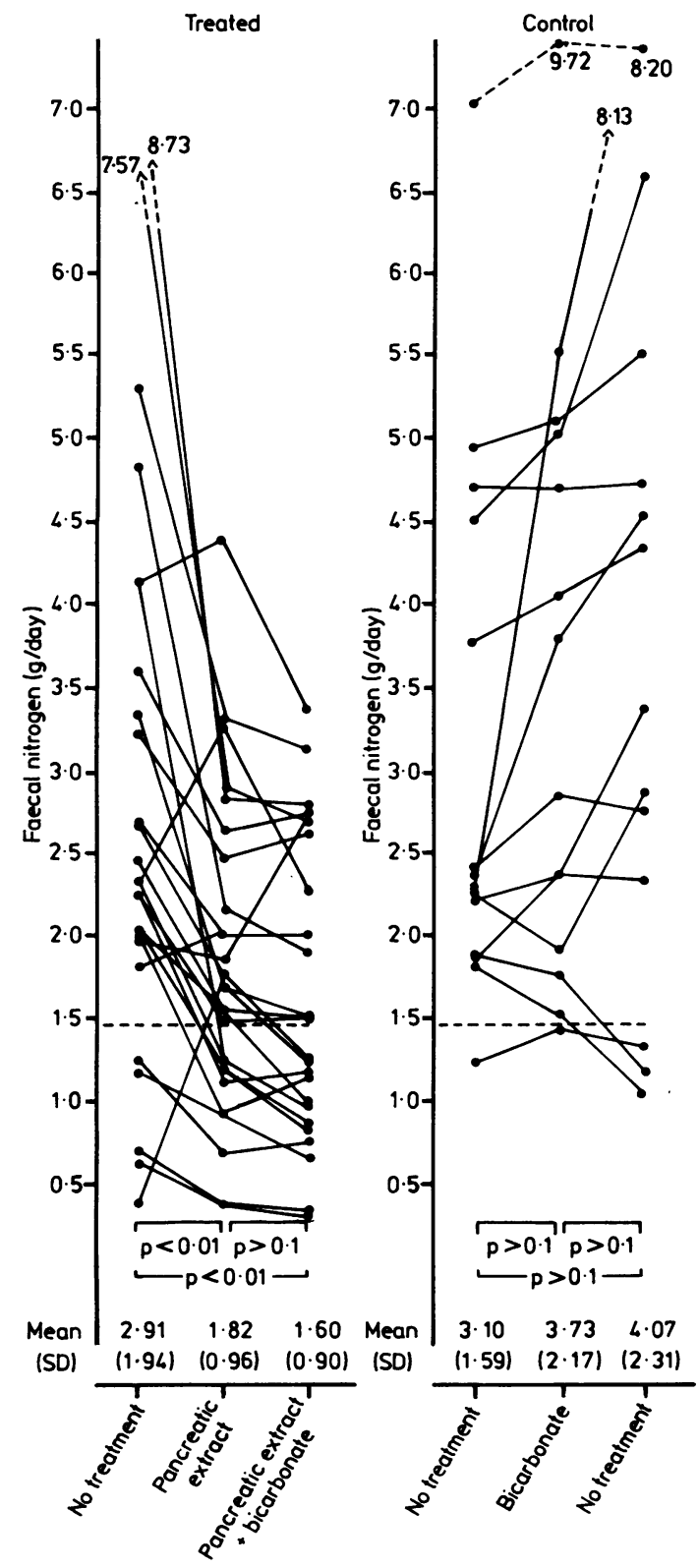

Fig. 2 Daily faecal nitrogen determined by three subsequent food balances in different treatment conditions in two groups of patients with cystic fibrosis. The 'treated' group received pancreatic extract (Pancrex $V$ powder, about $200 \mathrm{mg} / \mathrm{kg}$ body weight/day) or pancreatic extract (Pancrex $V$, same dose) plus sodium bicarbonate $\left(5 \cdot 2 \mathrm{~g} / \mathrm{m}^{2}\right.$ body surface/day); the 'control' group was treated with sodium bicarbonate alone $\left(5 \cdot 2 \mathrm{~g} / \mathrm{m}^{2}\right.$ body surface/day).
$75-90 \%$ ) in 18 , and insufficient (ACfat lower than $75 \%$ ) in only five.

With the conventional extract, out of a total of 27 treated patients and a total number of 27 food balances, there were only six in whom the ACfat was over $90 \%$, while in seven it was between 75 and $90 \%$, and in 14 it was well below $75 \%$.

Evaluation of a product containing fungal lipase and protease (Krebsilasi). Baseline ACfat was not modified at all by this product (from a mean (SD) of $47(15.5) \%$ to $49.5(13.6) \%$ ); faecal nitrogen improved to a very limited extent (from a mean (SD) of $4.82(1.5) \mathrm{g} /$ day to $3.82(2.2) \mathrm{g} /$ day $)$ compared with the results obtained from the other products. A similar trend was observed for daily faecal weight (from $357.7(102.8) \mathrm{g} /$ day to 246.4 $(55.4) \mathrm{g} /$ day). There was no significant difference in the variables measured between the baseline situation and after treatment.

\section{Discussion}

By using bicarbonate with a conventional extract it is possible to obtain an improvement in the digestive effect of the extract on fats, though this is limited. The effect is greater when the baseline steatorrhoea is more severe, and it is quantitatively comparable with that obtainable with cimetidine. ${ }^{11-13}$ No improvement in azotorrhoea can be obtained with bicarbonate. On the other hand, the overall faecal loss of nitrogen with the conventional extracts at high doses approaches closely to normal loss.

The preparations formulated to protect the extract against gastric inactivation were therefore considered with interest. Simple protection with cellulose acetatephthalate, as in the Pancrex V microgranules preparation, did not show any advantage. On the other hand, the preparations in $\mathrm{pH}$ sensitive gastroresistant and enterosoluble microspheres manufactured using more up to date methods were shown in our work to offer advantages. This conclusion was based on a larger set of cases than has generally been reported previously. ${ }^{2} 13 \quad 14 \quad 16-18$ Such preparations were undoubtedly more active in promoting fat absorption than the unprotected extracts. No improvement was evident, however, in loss of faecal nitrogen or daily faecal weight.

These results should be compared with those obtained by other workers, who have not always shown greater efficacy of the new types of formulation but only shown greater practicability. ${ }^{2} 1318$ In other words, they have usually stated that the same effect can be obtained with a smaller dose of $\mathrm{pH}$ sensitive extract compared with the conventional extracts. 

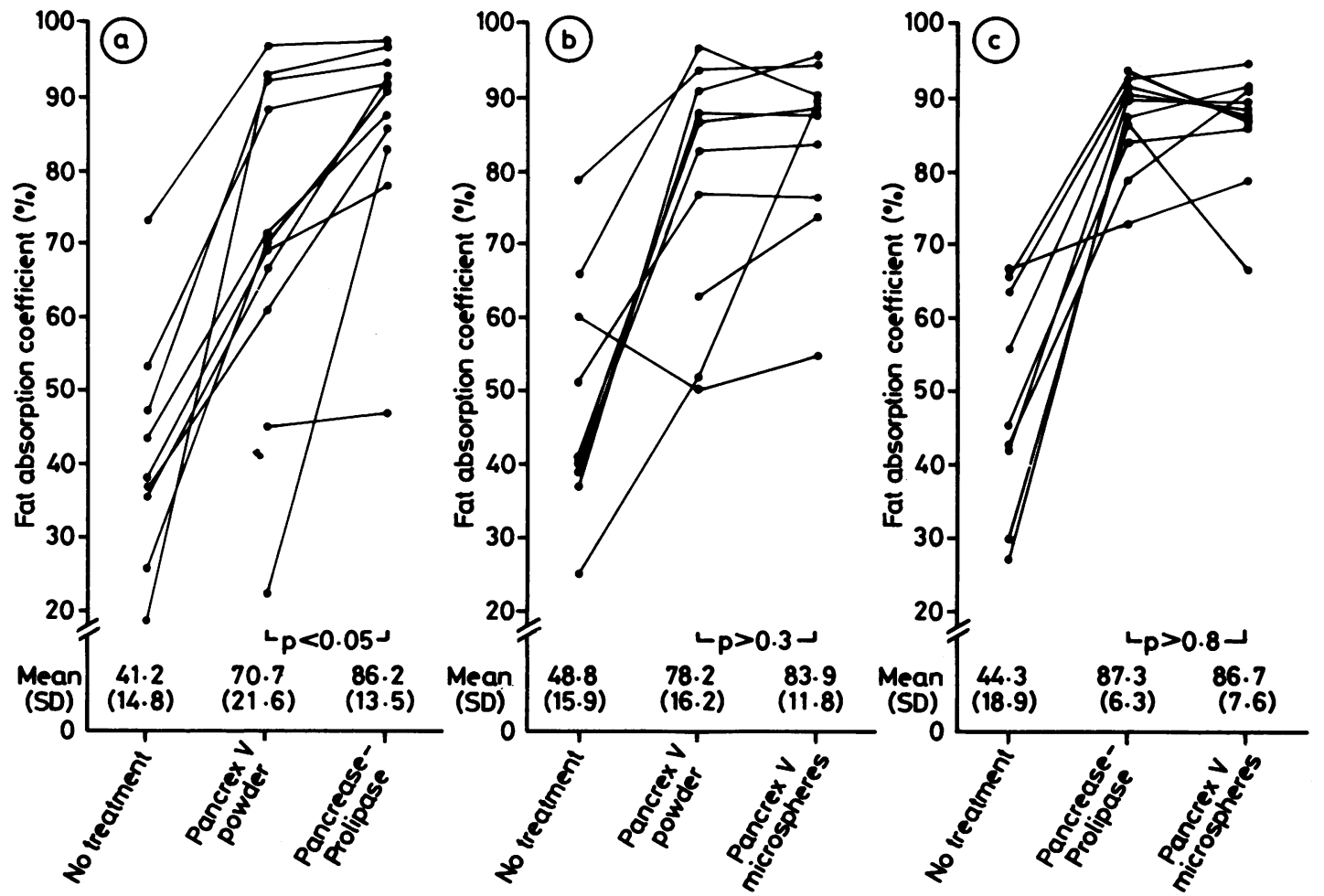

Fig. 3 Two groups of patients with cystic fibrosis were treated alternatively with a conventional pancreatic extract and new pH sensitive formulations ( $(a)$ and $(b)$, respectively)); a third group was treated with two different new formulations (c). Fat absorption coefficients on different treatments are compared with the baseline ones.

Much of the reported work on pancreatic extracts has been based on excessively small samples. ${ }^{2}$ 1.-18 In none of the experiments was the dosage related to the quantity of fats introduced, while evaluation of the results was often performed using ill defined variables. ${ }^{17}$ It is acknowledged that this type of trial is somewhat difficult from the methodological standpoint. There is in fact great variability of results from case to case, and it is difficult to obtain well matched groups of patients. It is enough to observe that in our experiments three groups of subjects (numbering six, 11 , and 10 , respectively), treated with the same dosage of Pancrex $V$ powder, gave three widely differing mean values for ACfatnamely, 65,70 , and $78 \%$, respectively. Only comparing patients in large groups, as was made possible by the complex design of this experiment, allowed a reliable and statistically valid comparison to be made between the different pancreatic extracts.

We are unable to say whether the results obtained with recent extracts can be produced with even lower dosages than those used, but it must be reiterated that they were obtained with an intake of enzymatic activity of about a third of that which had given the best but not optimal activity with the powdered pancreatic extracts, on the basis of a progressive dosage test. ${ }^{4}$

The product based mainly on acid stable enzymes of fungal origin proved to be ineffective in correcting steatorrhoea and azotorrhoea in patients with cystic fibrosis.

Lastly, it should be pointed out that there are resistant cases (perhaps $10 \%$ ) in whom no type of pancreatic extract nor any dietary addition can bring the digestion to acceptable equilibrium. These are the cases with either extensive ileal resection for meconium ileus or possible severe deficiency of resorption of bile acids. ${ }^{713}$ In these cases we have found that inhibition of gastric acid secretion by means of $\mathrm{H}_{2}$ antagonists has occasionally been successful, while there is the possibility of gaining some advantage by the use of bile salts to improve micellar concentration. 
We thank Laura Sancassani for editorial help and all the nurses of the Cystic Fibrosis Center in Verona for their management of patients under study and data collection.

\section{References}

${ }^{1}$ Durie PR, Newth CJ, Forstner GG, Fall DG. Malabsorption of medium-chain triglycerides in infants with cystic fibrosis: correction with pancreatic enzyme supplements. $J$ Pediatr 1980;96:862-4.

${ }^{2}$ Khaw KT, Adeniyi-Jones S, Gordon D, Palombo J, Suskind RM. Efficacy of pancreatic preparation on fat and nitrogen absorption in cystic fibrosis patients. Pediatr Res 1978;12:444.

${ }^{3}$ Mastella G, Trabucchi C. Sindromi da malassorbimento di origine pancreatica. Prospettive in Pediatria 1976;23:355-70.

${ }^{4}$ Mastella G. Nutritional problems in maldigestion and malabsorption in childhood. In: Muller HR, ed. Enzyme development and post-natal feeding. Vevey: Nestlé, 1975:115-38.

5 Young WC, Aviado DM. Clinical pharmacology for pediatricians. I. Pancreatic enzyme preparations, with special reference to enterically coated microspheres of pancrelipase. J Clin Pharmacol 1981;21:224-37.

${ }^{6}$ Di Magno EP, Malagelada JR, Moertel CG. Fate of orally ingested enzymes in pancreatic insufficiency: comparison of two dosage schedules. N Engl J Med 1977;296:1318-21.

${ }^{7}$ Roy CC, Weber AM, Morin CL. Abnormal biliary lipid composition in cystic fibrosis. N Engl J Med 1977;297:1301-5.

${ }^{8}$ Berndt W. Nachweis der Wirksamkeit von Nortase anhand von, Stuhlfett-Bilanzenalysen. Therapie Woche 1979;29:7095-102.

9 Pointner H. Flegel U. Die Behandlung der Exokrinen Pankreas insuffizienz mit Einer Saurestabilen Pilzlipase. Arzneimittelforsch 1975;11:1833-5.

10 Fredrikson B, Blackberg L. Lingual lipase: an important lipase in the digestion of dietary lipids in cystic fibrosis? Pediatr Res 1980;14:1387-90.

" Boyle BJ, Long WB, Balestrieri WF, Widzer SJ, Huang N. Effect of cimetidine and pancreatic enzymes on serum and fecal bile acids and fat absorption in cystic fibrosis. Gastroenterology 1980;78:950-3

12 Cox KL, Isenberg JN. The effect of cimetidine on maldigestion in cystic fibrosis. J Pediatr 1979;94:488-92.

13 Nassif EG, Younoszai MK, Weinberger MM, Nassif CM. Comparative effects of antacids, enteric coating, and bile salts on the efficacy of oral pancreatic enzyme therapy in cystic fibrosis. J Pediatr 1981;98:320-3.

14 Graham DY. An enteric coated pancreatic enzyme preparation that works. Dig Dis Sci 1979;24:906-9.

15 Gow R, Francis P, Bradbear R, Shepherd R. Comparative study of varying regimes to improve steatorrhoea and creatorrhoea in cystic fibrosis: effectiveness of an enteric-coated preparation with and without antacids and cimetidine. Lancet 1981;i:1071-4.

${ }^{16}$ Mischler EH, Parrell S, Farrell PM, Odell GB. Comparison of effectiveness of pancreatic enzyme preparations in cystic fibrosis. Am J Dis Child 1982;136:1060-3.

${ }^{17}$ Salen G, Prakash P. Evaluation of enteric-coated microspheres for enzyme replacement therapy in adults with pancreatic insufficiency. Nebr Symp Motiv 1979;25:650-6.

18 Warwick WJ, Budd JR. Comparison of two forms of entericcoated pancrelipase in six teenagers with cystic fibrosis. Clin Ther 1982;5:15-20.

${ }_{19}$ Mastella G, Barbato G, Trabucchi C, Mengoli V, Olivieri D, Rossi FA. The exocrine pancreas in cystic fibrosis. Functional studies in 169 patients and 118 controls. Italian Journal of Pediatrics 1975;1:109-30.

20) Jeejeebhoy KN, Ahmed S, Kozek G. Determination of fecal fats containing both medium and long chain triglycerides and fatty acids. Clin Biochem 1970;3:157-61.

${ }^{21}$ Kirsten W, Hesselius CV. Rapid, automatic, high capacity Dumas determination of nitrogen. Microchemical Journal 1983;28:529-47.

Correspondence to Professor G Mastella, Veneto Regional Research Centre for Cystic Fibrosis, Ospedale Borgo Trento, 37126 Verona, Italy.

Received 20 October 1986 